\title{
The Effect of The Existence of Large and Medium Industries on The Absorption of Labor in Sumatera Utara
}

\author{
Iskandar Muda \\ Universitas Sumatera Utara \\ Medan, Indonesia \\ iskandar1@usu.ac.id
}

\author{
Ratna Balqis Nasution \\ Universitas Harapan \\ Medan, Indonesia \\ nasutionratnabalqis@yahoo.com
}

\author{
Erlina \\ Universitas Sumatera Utara \\ Medan, Indonesi \\ erlina@usu.ac.id
}

\author{
Hasan Sakti Siregar \\ Universitas Sumatera Utara \\ Medan, Indonesia \\ hasan@usu.ac.id
}

\author{
Setareh Katircioglu \\ University of Kyrenia \\ North Cyprus, Via Mersin 10, Turkey \\ setareh.sodeyfi@gmail.com
}

\begin{abstract}
The purpose of this study is to see the influence and existence of large and medium industries in North Sumatra to absorb the number of workers in North Sumatra Province. The type of research is descriptive quantitative. The data used are secondary data sourced from Statistics Agency of North Sumatera Province. The results indicate the existence of large and medium industries that stood in North Sumatra Province have not impact on the absorption of the number of workers. The implications of this research with the existence of large and medium industry then North Sumatra provincial government should increase the allocation of local government expenditure funds to stimulate the entry of investors to North Sumatra so it can absorb labor in the City District.
\end{abstract}

Keywords-employment absorption; large industry; medium industry; local government; industrial stimulus

\section{INTRODUCTION}

The number of workers is the number of workers/employees on average per day of work both paid workers and unpaid workers. Production Workers are workers who work directly in the production process or in connection with it, including workers who directly oversee the production process, operate the machine, record the raw materials used and the goods produced [1]. The industry is an economic activity which undertakes the activity of converting a basic goods mechanically, chemically, or by hand into a finished or semi-finished product and/or a product of less value into higher value goods, and is closer to the last use. An industry is an enterprise or an industrial enterprise which is a unit of business to engage in economic activities, aiming to produce goods or services located in a particular building/location and having a separate administrative record of production and cost structure and there is one or more who is responsible for the business risk. According to [24], industry has two meanings, namely: First, industry can mean the set of similar companies. In this context, for example, the cosmetics industry means the set of cosmetics-producing companies; textile industry means the set of factories or textile companies. Second, the industry can lead to an economic sector in which there are productive activities that process raw materials into finished or semifinished goods. The processing activity itself can be electrical or manual. The existence of industries is an economic activity that processes raw materials, raw materials, semi-finished goods or finished goods into goods of higher value for use, including industrial engineering. The more industry stands, the more it absorbs the workforce, thus reducing unemployment and reducing the number of poor people.

The result of research by [27] summarizes the overall minimum wage of real province, GDP of industrial sector, foreign investment of industrial sector, domestic investment of industrial sector significantly influences to industrial labor absorption with confidence level of 95 percent. Partially, the PDRB of industry sector and provincial minimum wage have positive and significant influence to the employment of industrial sector. Investment in industrial sectors both domestically and abroad does not significantly affect the absorption of industrial sector workforce. Government intervention is needed so that the hope of creating a large 
employment in the industrial sector can be realized. The government should encourage the growth of the industrial sector to make the output or production produced higher by facilitating the licensing of establishing companies and increasing the export of industrial production goods. The government should also maintain the domestic market especially in the food industry by restricting imports of food from abroad so that the food industry can grow. Establishment of minimum wage standards needs to be carried out appropriately to certain wage levels that do not harm industrial companies. [3] concludes that industrial sector growth shows a declining trend while investment, wage and employment of the industrial sector shows an increasing trend, the growth rate of the industrial sector has no effect of industrial sector employment, while investment and wages have an effect to the employment of industrial sector in Central Java.

[24] concludes that researching under the title Foreign Capital Investment and Absords Labor In The Industry Sector find the presence of foreign investors in Indonesia contributes more to improving capital-intensive industries compared to labor-intensive industries. Goal of government in reducing the unemployment rate is still difficult to achieve if industrial improvement capital-intensive is only able to absorb a little labor with educational qualifications and high skills [10]. The condition of Indonesia's labor force is still dominated by workers with less competitive levels of education and skills. Even based on the efficiency figures required a relatively high investment to absorb the workforce of the industry that the investor targets foreign. This condition is exacerbated by the declining competitiveness of Indonesia in attracting foreign investors. The effort required to deal with these conditions is an improvement the role of government in creating investment climate, among others through improvement infrastructure facilities and make regulations on investment in. one packages integrated with other regulations related to business activities in Indonesia [15]. Other than that, the government can also ensure that local workforce assistance to foreign emphasis on technology transfer and expertise so that it can gradually improve the skills required in accordance with technology development [3],[8],[9],[24] \& [25] \&[26].

\section{METHOD}

This analysis is used to solve quantitative problems. This study uses secondary data. The data were obtained from Central Bureau of Statistics. North Sumatera In Figures in the period 2000-2015. It is a descriptive-quantitative research that is a research defines an existing phenomenon and describes it clearly from the research object. The hypothesis was tested by using SMART PLS software. SEM allows able to answer the research that is regressive and dimensional and also be used simultaneously to measure the effect or the degree of relationship among the factors where its dimensions have been identified [14],[16],[21]\&[26]. SEM is a set of statistical techniques allowing testing of a series of relationships simultaneously. Furthermore, in the data processing, the writer used the aid from software Smart-PLS Structural Equation Modeling, which was one of the multivariate analyses capable of analyzing the variable relationships in complex manner [4],[5],[6],[7],[13]\&[17]. Testing criteria used is if $t_{\text {count }}>t_{\text {table }}$ then Ho rejected; and if $t_{\text {count }} \leq t_{\text {table }}$ then Ho is acceptable [10],[11] \& [12]. The hypotheses were tested using SEM with Smart-PLS software tools. This phase is done to test the suitability of the model to evaluate the goodness-of-fit index. Analysis using SEM requires some suitability index to measure the correctness of data and models [17],[18] \& [19]. The equation is formed as follows:

$\begin{array}{ll} & \mathrm{Y}_{2}=\alpha+\mathrm{b}_{1} \mathrm{X}_{1}+\mathrm{b}_{2} \mathrm{X}_{2}+\mathrm{e} \\ \mathrm{X}_{1} & =\text { Large industries } \\ \mathrm{X}_{2} & =\text { Medium industries } \\ \mathrm{Y}_{2} & \text { Absorption of the number of workers } \\ \mathrm{b}_{1}, \mathrm{~b}_{2} & =\text { Coefficient } \\ \alpha & =\text { Constant } \\ \mathrm{e} & =\text { Error }\end{array}$

\section{RESULT}

The measurement model links between latent variables with manifest variables as follows:

Table 1. Regression Weights: (Group number 1 - Default model)

\begin{tabular}{|rr|rrrrr|}
\hline & & Estimate & S.E. & C.R. & P & Label \\
\hline Y2 <--- & X1 & 971,241 & 1622,714 &, 599 &, 549 & par_1 \\
Y2 <--- & X2 & $-2539,118$ & 4161,600 &,- 610 &, 542 & par_2 \\
\hline
\end{tabular}




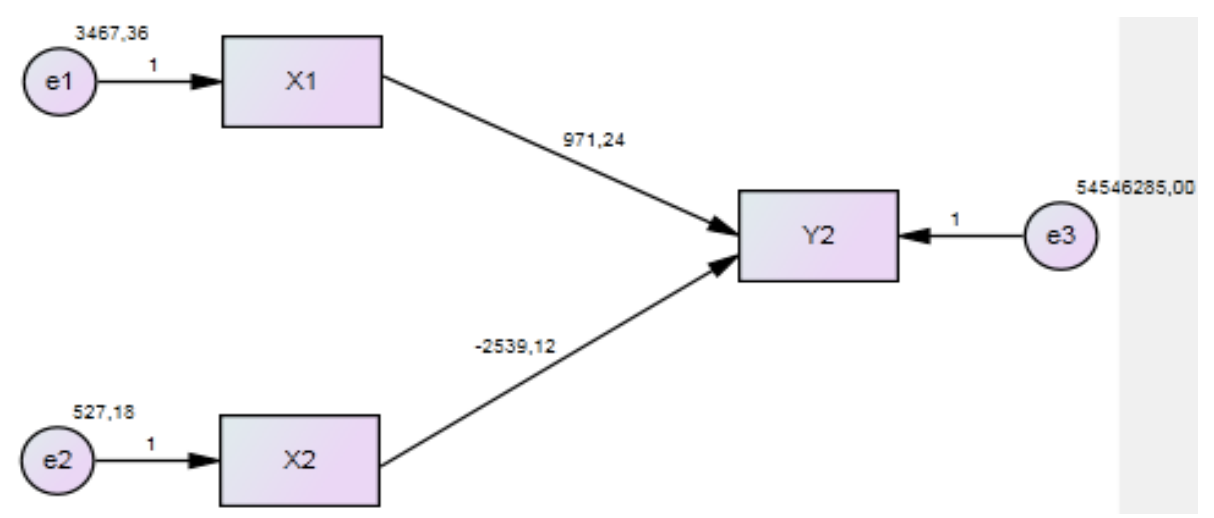

Figure 1. Standardization Coefficient

The test results conclude that the existence of large and medium industries in North Sumatra has no significant impact on employment. If associated with economic growth, the existence of large and medium industries in North Sumatra can increase economic growth but not able to absorb the number of workers. Economic growth is very important and needed, because without economic growth will not increase welfare, employment, productivity, and income distribution. Growth the economy is also important to prepare the economy to go through the stages of progress. The following are the main factors that cause an industry/industry to grow properly if owned, among others are: [8]. [20]

\section{A. Main Factor}

1) Capital

Capital is used to build assets, purchase of raw materials, recruitment of labor, and so forth to run industrial activities [21]. Capital can come from within a country as well as from abroad called as foreign investment.

\section{2) Labor}

Manpower with the number and quality standards that suit the needs of industry will certainly make the industry become fluent and can be developed in the future. If a country is overproduced, then one good solution is to send labor abroad to foreign workers.

\section{3) Raw Materials /Raw Materials}

Raw materials are one important element that greatly affects the production activities of an industry. Without sufficient raw materials then the process of producing can be hampered and even halted. Therefore, the supply of raw materials that are good enough from within and outside the country/ import can accelerate the development of an industry.

\section{4) Transportation}

Very vital transport facilities required an industry either to transport raw materials to industrial sites, transporting and delivering labor, transporting finished goods industrial output to distributors/agents or to the next stage of production, and so forth. Imagine when transportation for the activity was disconnected.

\section{5) Energy Sources/Energy}

Modern industries require energy resources to run various production machines, turn on work-supporting equipment, run industrial vehicles and so on. Energy sources can exist in various forms such as fuel oil, coal, natural gas, electricity, methane, batteries, and so forth.

\section{6) Marketing/Marketing Results Output Production}

The marketing of products produced by the production output must be managed by the right people so that the products can be sold to obtain the expected profit as an income to finance the next production activity, expand market share, give dividends to shareholders, pay employees, employees, and others.

\section{B. Supporting Factor/Supporting Factors}

\section{1) Culture Society}

Before building and running industrial activities should be learned about customs, norms, values, habits, and so forth in the environment. Not sensitive to the life of the surrounding community is capable of causing conflict with the surrounding population. In addition, the ability to read the market can also make the products are not sold in the market because it is not in accordance with the tastes of consumers, not affordable purchasing power, consumer boycott, and others.

\section{2) Technology}

With the development of technology from time to time will help the industry to produce more effectively and efficiently and able to create and produce more modern and high-tech goods.

\section{3) Government}

Government is an important part in the development of an industry because all regulations and industrial policies are established and implemented by the government and its apparatuses [23] \& [28]. A stable government is able to support industrial development in terms of security, convenience, subsidies, light capital provision, and so on [22].

\section{4) Community Support}

The spirit of people to want to build their region or country will help the industry around it. People who quickly 
adapt to industrial development both in the village and in the city will greatly support the success of an industry.

\section{5) Natural Condition}

Good natural conditions and a friendly climate will help the industry facilitate its business activities. In Indonesia has a tropical climate without much extreme weather so that the average production activity can run well throughout the year.

\section{6) Economic Conditions}

Good and high income society will increase the purchasing power of people to buy industrial products, so the effect will be very good for the development of local and international industries. In addition, a good distribution channel to deliver goods and services from the hands of producers to consumers is also a very important thing.

The economy in the second quarter of 2017 is estimated to be quite good at 5.3-5.7\% (yoy) [2]. Economic growth in the quarter is expected to be sourced from strong domestic demand and an improvement from the external side although still relatively limited. The upcoming economy is also expected to be tempered by rising inflationary pressures as demand grows according to seasonal patterns amid the limited supply of food. Overall year, the economy of North Sumatra in 2017 is estimated to improve compared to the previous year and is in the range of $5.2 \%-5.6 \%$. The improvements were driven by improving domestic demand and increasing export performance. The improvement of the economy in 2017 is accompanied by an inflation rate that is expected to be in the range of $4.0 \pm 1 \%$, or decline compared to 2016 [2]. The low inflationary pressure in 2017 is supported by the food supply that is returning to normal. Meanwhile, inflation risks are estimated to come from administered prices inflation.

\section{CONCLUSIONS}

The results indicate the existence of large and medium industries that stood in North Sumatra Province have not impact on the absorption of the number of workers. The implications of this research with the existence of large and medium industry then North Sumatra provincial government should increase the allocation of local government expenditure funds to stimulate the entry of investors to North Sumatra so it can absorb labor in the City/District.

\section{REFERENCES}

[1]. Azlina, Nur. Amir Hasan, Desmiyawati \& Muda, I. "The Effectiveness of Village Fund Management (Case Study at Villages in Coastal Areas in Riau)". International Journal of Economic Research. Vol. 14 Issue 12. (2017). pp.325-336.

[2]. Central Bureau of Statistics. North Sumatera In Figures 2016. Republic of Indonesia. Jakarta. (2016).
[3]. Chusna, A. "The Effect of Industrial Growth Rate, Investment, and Wages on the Absorption of Industrial Sector Workers in Central Java Province 1980-2011”. Economics Development Analysis Journal, 2(3). (2013).

[4]. Dalimunthe, D.M.J.,Fadli, and Muda, I. "The application of performance measurement system model using Malcolm Baldrige Model (MBM) to support Civil State Apparatus Law (ASN) number 5 of 2014 in Indonesia". International Journal of Applied Business and Economic Research. Vol.14 Issue 11. (2016). pp.7397-7407.

[5]. Erlina, Ari Saputra \& Muda, I. "Antecedents of Budget Quality Empirical Evidence from Provincial Government In Indonesia". International Journal of Economic Research. Vol. 14 Issue 12. (2017). pp.301-312.

[6]. Erlina. Ari Saputra \& Muda, I. "The Analysis of the Influencing Factors of Budget Absorption". International Journal of Economic Research. Vol. 14 Issue 12. (2017). pp.287-300.

[7]. Erlina. "Conflict of Interest Impact: Factors Analysis Affecting the Budget Quality in Medan City". International Journal of Economic Research.Vol.14 Issue 12. (2017). pp.135-145.

[8]. Firmansyah, H., \& Soebagyo, D. "Analysis of Factors Affecting the Absorption of Large and Medium Industry Sector Workers In Cities of Central Java Province 2010-2014”. Doctoral dissertation, (2017). Muhammadiyah University of Surakarta)

[9]. Fridhowati, Nila \& Mulatsih,Sri. "Factors Affecting the Absorption of Industrial Sector Labor In Java". Thesis Unpublished. 2013. U http://repository.ipb.ac.id/handle/123456789/53569

[10]. Gusnardi, Riadi, R.M., and Muda, I. "Competency mapping and analysis of students competency based on economics subject national examination and its alternative solutions in state high schools at Pekanbaru". International Journal of Economic Research. Vol.3 Issue 5. (2016). pp.2133-2148.

[11]. Handoko, Bagus. Sunaryo \& Muda, I. "Difference Analysis of Consumer Perception of Motorcycle Product Quality". International Journal of Economic Research. Vol. 14 Issue 12. (2017). pp.363-379.

[12]. Hasan, Amir, Gusnardi \& Muda, I. "Analysis of Taxpayers and Understanding Awareness Increase in Compliance with Taxpayers Individual Taxpayers". International Journal of Economic Research. Vol.14 Issue 12. (2017). pp. 75-90.

[13]. Lubis, A.,Torong, Z.B., and Muda, I. "The urgency of implementing balanced scorecard system on local government in North Sumatra - Indonesia". International Journal of Applied Business and Economic Research. Vol.14 Issue 11. (2016). pp.7575-7590.

[14]. Lubis, A.F., Lubis, T.A., and Muda, I. "The role of Enterprise Resource Plan (ERP) configuration to the timeliness of the financial statement presentation". International Journal of Applied Business and Economic Research. Vol.14 Issue 11. (2016). pp.7591-7608.

[15]. Lutfi, M.,Nazwar, C., and Muda, I. "Effects of investment opportunity set, company size and real activity manipulation of issuers in Indonesia Stock Exchange on stock price in Indonesia". International Journal of Economic Research. Vol.13 Issue 5. (2016). pp.2149-2161.

[16]. Muda, I and Abykusno Dharsuky. "Impact of Region Financial Information System (SIKD) Quality, Role Ambiguity And Training on Precision of Financial Statement of Local Government Presentation In North Sumatra". International Journal of Applied Business and Economic Research, Vol.13 Issue 6. (2015). pp.4283-4304.

[17]. Muda, I, Deni Yuwilia Wardani, Erlina, Azhar Maksum, Ade Fatma Lubis and Rina Bukit. "The Influence of Human Resources Competency and The Use of Information Technology on The Quality of Local Government Financial Report with Regional Accounting System as an Intervening”. Journal of Theoretical and Applied Information Technology. Vol.95 Issue 17. (2017). pp.1432-1451. 
[18]. Muda, I, Dharsuky. A., Siregar, H.S., and Sadalia, I. "combined loading and Cross-dimensional loadings timeliness of presentation of financial statements of local government". IOP Conference Series : Materials Science and Engineering. Bandung, (2017). 180. doi: $10.1088 / 1757-899 X / 180 / 1 / 012099$.

[19]. Muda, I, Marlon Sihombing, Erni Jumilawati and Abikusno Dharsuky. "Critical Success Factors Downstream Palm Oil Based Small And Medium Enterprises (SME) In Indonesia”. International Journal of Economic Research. Vol.13 Issue 8. (2016). pp. 3531-3538.

[20]. Muda, I., Rafiki, A., \& Harahap, M. R. "Factors Influencing Employees' Performance: A Study on the Islamic Banks in Indonesia". International Journal of Business and Social Science, Vol.5 Issue 2. (2014). pp. 73-80.

[21]. Muda, I.,Dharsuky, A.,Sadalia, I., and Siregar, H.S. "Impact of capital investments and cash dividend policy on Regional Development Bank (BPD) PT. Bank Sumut to the district own source revenue and economic growth". International Journal of Applied Business and Economic Research. Vol.14 Issue 11. (2016). pp.7863-7880.

[22]. Muda, Iskandar. "The Effect of Supervisory Board Cross-Membership and Supervisory Board Members' Expertise to The Disclosure of Supervisory Board's Report : Empirical Evidence From Indonesia". European Research Studies Journal.Vol.XX Issue 3A. (2017). pp.702-716.
[23]. Nasir, Azwir. Yesi Mutia Basri, Kamaliah \& Muda, I. "Effectiveness of Potential Tax Region as the Real Local Revenue Sources in Riau Coastal Area". International Journal of Economic Research. Vol. 14 Issue 12. (2017). pp.313-324.

[24]. Ningrum, Vanda. "Foreign Capital Investment and Absorbs Labor In The Industry Sector". Indonesia Population Jornal. Vol.3 Issue 2, (2008). pp.29-43.

[25]. Pangastuti, Y. "Analysis of Factors Influencing The Employment Of Labor In Central Java Province". Economics Development Analysis Journal, 4(2), (2017). pp.203-211.

[26]. Sadalia, .Isfenti. Nur Ahmadi Bi Rahamani \& Muda, I. "The Significance of Internet Based Financial Information Disclosure on Corporates' Shares in Indonesia". International Journal of Economic Research. Vol. 14 Issue 12. (2017). pp.337-346.

[27]. Safatillah, M. B. "Analysis of Factors Affecting the Absorption of Labor in the Electronic Industry in Indonesia". Economics Development Analysis Journal, 3(2). (2014). pp.55-69.

[28]. Yahya, Idhar., Torong, Z.B. and Muda, I.."Influence Behavior in Legislature Budget Development of Regions in the Province of Aceh and North Sumatra". International Journal of Economic Research, Vol.14 Issue 8. (2017). pp. 147-159. 